\title{
Tingkat Kepercayaan dan Minat Terhadap Investasi Obligasi Syariah pada Mahasiswa UIN Sunan Gunung Djati Bandung di Masa Normal Baru
}

\author{
Trust and interest in sharia bonds investment in students of UIN Sunan Gunung Djati Bandung \\ in the new normal period
}

\section{Anggun Rositawati Adibrata}

Fakultas Ekonomi dan Bisnis Islam, UIN Sunan Gunung Djati Bandung

E-mail: anggun1999adi.brata@gmail.com

\section{Neneng Hartati}

Fakultas Ekonomi dan Bisnis Islam, UIN Sunan Gunung Djati Bandung

E-mail: neneng.hartati@uinsgd.ac.id

\section{Vemy Suci Asih}

Fakultas Ekonomi dan Bisnis Islam, UIN Sunan Gunung Djati Bandung E-mail: just.vemy@gmail.com

\begin{abstract}
This study discusses the relationship between Trust Level as $\left(X_{1}\right)$ and Interest as $\left(X_{2}\right)$ on Sharia Bond Investment (Y) in UIN Sunan Gunung Djati Bandung students as research targets. The method used in this research is a survey method by distributing questionnaires to get 100 respondents and using a quantitative approach. The purpose of this study is to determine how much influence it has on each variable for the results of the study indicate that the Trust Level has a significant positive effect on Islamic Bond Investment. Then the students' interest in a relationship to Sharia Bond Investment is 0.578. Calculated by the correlation test and determination test.
\end{abstract}

Keywords: trust, interests, students, sharia bond investment

\section{Pendahuluan}

Pada era sekarang ini, perekonomian global berkembang sangat pesat Mempengaruhi perekonomian Indonesia. Salah satunya adalah Kegiatan pasar modal menjadi pilihan atau pilihan masyarakat Investor yang ingin melakukan investasi yang diantisipasi Kepentingan masa depan. Investasi adalah suatu bentuk Metode keuangan yang didistribusikan sebagian digunakan sebagian Terdaftar. Beberapa jenis investasi, salah satunya Investasi di pasar saham. Investasi dilakukan oleh Terdaftar. Ada berbagai macam investasi. Salah satunya adalah penanaman Investasi di pasar modal.

Munculnya pemikiran ekonomi Islam adalah gagasan tentang umat Islam yang berusaha memberi manfaat bagi masyarakat di dunia. Tujuan utamanya bukan untuk bersaing dengan sistem ekonomi kapitalis, tetapi untuk memperbaiki hal-hal buruk dalam sistem ekonomi kapitalis. Oleh karena itu, sistem ekonomi Islam berlaku tidak hanya untuk umat Islam tetapi juga untuk umat Islam.

Sejak booming ekonomi Islam dalam beberapa tahun terakhir, berbagai alat pasar modal syariah bermunculan. Sejak reksa dana Danareksa Investment Management diluncurkan pada tahun 
1997, obligasi syariah muncul pada akhir tahun 2002. Perkembangan lembaga dan perangkat keuangan Islam merupakan bagian penting dari perkembangan keuangan Islam. Hal ini agar doktrin surga mengakar, hanya perkembangan konsep dan teori, sehingga tidak hanya berada pada tataran normatif.

Sebagaimana kita ketahui bersama, obligasi syariah telah banyak digunakan di banyak negara Timur Tengah seperti Yordania, Dubai, Turki dan Malaysia. Jenis transaksi yang juga dikenal dengan model obligasi Islam atau biasa disebut dengan obligasi Muqaradhah-telah mendapat persetujuan dari IOC Academy untuk menggantikan obligasi berbunga. Di Indonesia, PT menerbitkan obligasi syariah gelombang pertama. Tak lama kemudian, beberapa emiten Indosat menerbitkan obligasi syariah. Artikel ini akan membahas masalah yang ditimbulkan oleh sukuk tersebut.

\section{Metode Penelitian}

Metode penelitian yang digunakan adalah desain survei yang menggunakan media berupa kuesioner sebagai alat penelitian untuk memperoleh data mentah. Studi survei ini adalah studi kuantitatif. Penelitian kuantitatif biasanya dilakukan dalam bentuk penelitian survei, yang menjelaskan hubungan antara variabel bebas dan variabel terikat yaitu variabel pengetahuan produk halal terhadap variabel pembelian. Dalam penelitian ini diambil 100 orang sampel mahasiswa UIN bandung. Teknik analisis data yang digunakan adalah analisis statistik kuantitatif yang bertujuan untuk mengetahui dan menganalisis hubungan antar variabel dalam penelitian ini.

\section{Hasil dan Pembahasan}

\subsection{Pengaruh Kepercayaan Mahasiswa Terhadap Investasi Obligasi Syariah}

Sikap (attitudes) konsumen adalah faktor penting yang akan mempengaruhi keputusan konsumen. Konsep sikap sangat terkait dengan konsep kepercayaan (trust) dan perilaku (behavior). Mowen dan Minor menyebutkan bahwa istilah pembentukan sikap konsumen (consumer attitude formation) seringkali menggambarkan hubungan antara kepercayaan, sikap dan perilaku. Kepercayaan, sikap dan perilaku memiliki hubungan timbal balik yang saling mempengaruhi dalam pengambilan keputusan. Ketiganya saling mempengaruhi, yang mana kepercayaan akan mempengaruhi seseorang dalam bersikap. Sikap seseorang akan membentuk perilaku seseorang (Ujang Sumarwan,2002).

Selain kepercayaan yang telah dijelaskan secara umum, Allah SWT juga telah menjelaskan kepercayaan dalam Islam yang disebut dengan amanah (dapat dipercaya). Sebagaimana yang terkandung dalam surat An-Nisa ayat 58 yang berbunyi:

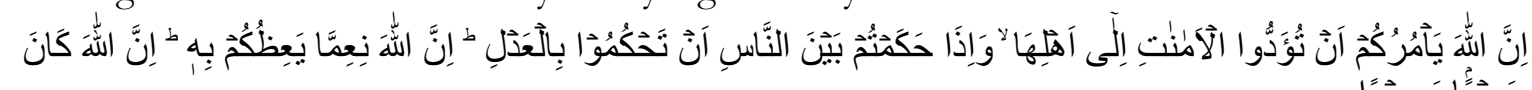

Artinya: "Sesungguhnya Allah menyuruh kamu menyampaikan amanat kepada yang berhak menerimanya, dan (menyuruh kamu) apabila menetapkan hukum di antara manusia supaya kamu menetapkan dengan adil. Sesungguhnya Allah memberi pengajaran yang sebaik-baiknya kepadamu. Sesungguhnya Allah adalah Maha mendengar lagi Maha melihat".

Obligasi merupakan suatu surat berharga (efek) berjangka waktu menengah dan panjang, yang merupakan bukti pengakuan utang dari penerbit dan dapat diperjual belikan. Terdapat tempat struktur yang dimiliki obligasi yaitu prinsipal (nilai penerbitan obligasi), harga obligasi, kupon, dan jatuh tempo (Rahardjo,2013).

Menurut Keputusan Menteri Keuangan RI No. 755/KMK.011/1982. Pasal 1 (a) yang dikutip oleh Junaedi bahwa obligasi adalah jenis efek berupa surat pengakuan utang 
atas pinjaman uang dari masyarakat dalam bentuk tertentu, untuk jangka waktu sekurangkurangnya tiga tahun dengan menjanjikan imbalan bunga yang jumlah setara serta saat pembayarannya telah ditentukan terlebih dahulu oleh emiten (Junaedi,1990: 4).

Menurut etimologi obligasi berasaldari bahasa Belanda (obligatie) yangberarti surat jaminan pemerintah.(Rahajoekoessoamah,1995:937)

Kepercayaan investasi obligasi dikarenakan investasi obligasi lebih aman dibandingkan dengan investasi saham. Jika perusahaan mengalami likuiditas, pemegang obligasi memiliki hak pertama atas aset perusahaan karena perusahaan telah mengikat kontrak untuk melunasi obligasi yang telah dibeli oleh pemegang obligasi (Pandutama,2012).

Obadovic et al melakukan penelitian dengan menghitung nilai VaR obligasi dengan tingkat kepercayaan 90\%, 95\%, 99\%, dan 99,5\% menggunakan Delta Normal Method (Obadovic et al,2016).

Memilih obligasi dengan tingkat kerugian terkecil merupakan salah satu prioritas seorang investor. Investor bisa menentukan nilai V alue at-Risk (VaR) terlebih dahulu untuk mengetahui maksimum kerugian yang akan didapat saat melakukan investasi. VaR mengukur maksimum kerugian dari sebuah aset atau portofolio untuk rentang waktu tertentu pada tingkat keyakinan tertentu di bawah kondisi pasar yang normal (Jorion,2007).

Kaitan dengan Pernelitian ini, didapatkan hasil pengujian hipotesis yang menunjukan adanya pengaruh variabel Kepercayaan (X1) Minat (X2) terhadap Investasi Obligasi Syariah (Y) secara parsial dapat dilihat pada table berikut:

Tabel. 1 Hasil Regresi (Variabel Kepercayaan)

Coefficients $^{\mathrm{a}}$

\begin{tabular}{|c|c|c|c|c|c|c|}
\hline \multirow{2}{*}{\multicolumn{2}{|c|}{ Model }} & \multicolumn{2}{|c|}{$\begin{array}{c}\text { Unstandardized } \\
\text { Coefficients }\end{array}$} & $\begin{array}{c}\text { Standardized } \\
\text { Coefficients }\end{array}$ & \multirow[t]{2}{*}{$\mathrm{t}$} & \multirow[t]{2}{*}{ Sig. } \\
\hline & & B & Std. Error & Beta & & \\
\hline \multirow{3}{*}{1} & (Constant) & 3,372 & 885 & & 3,810 & ,000 \\
\hline & Kepercayaan & ,045 & ,077 & ,063 & ,584 &, 560 \\
\hline & Minat & ,375 &, 075 &, 536 & 5,009 & ,000 \\
\hline
\end{tabular}

a. Dependent Variable: Investasi Obligasi Syariah (Y)

$$
\mathrm{Y}=3,372+0,045+0,375
$$

Dengan demikian, dapat disimpulkan bahwa variabel Kepercayaan Mahasiswa (X1) berpengaruh positif dan signifikan terhadap variabel Investasi Obligasi Syariah (Y).

\subsection{Pengaruh Minat Mahasiswa Terhadap Investasi Obligasi Syariah}

Minat adalah kecenderungan seseorang untuk memilih melakukan suatu kegiatan tertentu diantara sejumlah kegiatan lain yang berbeda (Saparinah, Depdikbud, 1982). Minat merupakan kecenderungan afektif seseorang untuk membuat pilihan aktivitas, kondisi-kondisi individual dapat merubah minat seseorang. Sesuai dengan pengertian di atas maka dapat disimpulkan bahwa minat adalah fungsi kejiwaan atau sambutan yang sadar untuk tertarik terhadap suatu objek baik berupa benda atau yang lain. Minat terhadap investasi obligasi syariah salah satunya karena ada gaya tarik dari luar dan juga datang dari hati sanubari. Minat yang besar terhadap suatu hal merupakan modal yang besar untuk mencapai tujuan yang diminati terutama di sektor investasi obligasi syariah.

Menurut pendapat dari Abu Ahmadi dan Widodo Supriyono disadur Harnanto, ada beberapa ciri-ciri minat yang dapat didefinisikan, antara lain: (1) cara mengikuti aktivitas pada dunia yang diminati; (2) serius tidaknya dalam mengikuti aktivitas (Harnanto,2006).

Hubungan dengan penelitian ini,dapat dilihat dari pengujian hipotesis yang memperlihatkan adanya hubungan dan pengaruh terhadap setiap variable yakni Variable Minat $\left(\mathrm{X}^{2}\right)$ terhadap 
Variabel Investasi Obligasi Syariah (Y) secara parsial yang dapat ditunjukan pada table berikut:

Tabel. 2 Hasil Regresi (Variabel Minat)

Coefficients $^{\mathrm{a}}$

\begin{tabular}{|c|c|c|c|c|c|}
\hline \multirow[t]{2}{*}{ Model } & \multicolumn{2}{|c|}{$\begin{array}{l}\text { Unstandardized } \\
\text { Coefficients }\end{array}$} & $\begin{array}{c}\text { Standardized } \\
\text { Coefficients }\end{array}$ & \multirow[t]{2}{*}{$\mathrm{t}$} & \multirow[t]{2}{*}{ Sig. } \\
\hline & B & Std. Error & Beta & & \\
\hline (Constant) & 3,372 & ,885 & & 3,810 &, 000 \\
\hline Kepercayaan & ,045 & ,077 & ,063 & ,584 & ,560 \\
\hline Minat & ,375 & ,075 &, 536 & 5,009 &, 000 \\
\hline
\end{tabular}

b. Dependent Variable: Investasi Obligasi Syariah (Y)

Dengan demikian, dapat disimpulkan bahwa variabel Minat (X2) berpengaruh positif dan signifikan terhadap variabel Investasi Obligasi Syariah (Y).

\subsection{Pengaruh Kepercayaan dan Minat Mahasiswa Terhadap Investasi Obligasi Syariah}

Obligasi syariah atau sukuk adalah surat berharga sebagai instrumen investasi yang diterbitkan atas dasar suatu transaksi atau kas syariah yang melandasinya (underlying transaction), yang berupa akad musyarakah, ijarah, mudharabah, dan lain sebagainya. Sukuk yang saat ini banyak diterbitkan adalah berdasar akad ijarah atau sewa, dimana hasil investasi berasal dan dikaitkan dengan arus pembayaran sewa aset tersebut. Obligasi juga dapat diterbitkan berdasar akad syariah lain (Huda\& Edwin,2008).

Fatwa Dewan Syariah Nasional (DSN) No. 32/DSN-MUI/IX/2002, obligasi syariah adalah suatu surat berharga jangka panjang berdasarkan prinsip syariah yang dikeluarkan emiten kepada pemegang obligasi syariah yang mewajibkan emiten untuk membayar pendapatan kepada pemegang obligasi syariah berupa bagi hasil, margin, serta membayar kembali dana obligasi pada saat jatuh tempo. (Sudarsono, 2004: 223)

Penerbitan obligasi dilakukan oleh perusahaan yang membutuhkan dana. Perusahaan menerbitkan obligasi untuk memenuhi kebutuhan keuangan dalam jangka pendek maupun jangka panjang serta untuk melakukan ekspansi bisnisnya. Akad yang biasa digunakan oleh perusahaan dalam menerbitkan obligasi korporasi antara lain akad ijarah, mudharabah, murabahah, musyarakah, istishna,dan salam.

Investasi obligasi korporasi di Indonesia yang baik diperlukan suatu kondisi perekonomian yang kondusif. Investasi yang kondusif sangat erat kaitannya dengan kondisi ekonomi makro dalam negeri. Kodisi ekonomi makro yang membaik memiliki dampak pada kegiatan investasi menjadi positif. Kondisi ekonomi makro tersebut antara lain produk domestik bruto, jumlah uang beredar, inflasi, nilai tukar, serta kondisi ekonomi makro lainnya (Antonio et al.,2013).

Dengan banyaknya informasi yang mahasiswa dapatkan tentang investasi obligasi syariah serta tingkat kepercayaan yang tinggi dan di dukung dengan minat dari mahasiswa untuk melakukan investasi obligasi syariah, maka mahasiswa dapat melakukan investasi obligasi syariah tanpa ragu.

Kaitan dengan penelitian ini, didapatkan hasil pengujian hipotesis yang menunjukan adanya hubungan antara kepercayaan mahasiswa (X1) dan minat (X2) secara simultan berpengaruh signifikan terhadap investasi obligasi syariah.

Tabel. 3 Anova

\begin{tabular}{|l|r|r|r|r|r|}
\hline Model & $\begin{array}{c}\text { Sum of } \\
\text { Squares }\end{array}$ & df & Mean Square & F & \multicolumn{1}{c|}{ Sig. } \\
\hline $1 \quad$ Regression & 76,088 & 2 & 38,044 & 24,299 &, $000^{\mathrm{b}}$ \\
\hline
\end{tabular}




\begin{tabular}{|l|r|r|r|r|r|}
\hline Residual & 151,872 & 97 & 1,566 & & \\
Total & 227,960 & 99 & & & \\
\hline
\end{tabular}

a. Dependent Variable: Investasi Obligasi Syariah

b. Predictors: (Constant), Minat, Kepercayaan

Dalam perhitungan table ANOVA diatas dapat dilihat nilai signifikasi $0.000>0,05$ yang menujukan bahwa kepercayaan mahasiswa dan minat berpengaruh secara signifikan terhadap investasi obligasi syariah. F hitung sebesar 24,299 dan $\mathrm{F}$ table $(3,09)$ juga tingkat signifikan 0.05 yaitu sebesar 3.09 yang berarti $\mathrm{F}$ hitung $>\mathrm{F}$ table $(24,299>3,09)$. Dengan demikian dapat disimpulkan bahwa variabel Kepercayaan Mahasiswa (X1) dan Minat (X2), berpengaruh positif serta signifikan terhadap variabel Investasi Obligasi Syariah (Y).

Tabel. 4 Hasil Regresi (Keseluruhan)

Coefficients $^{\mathrm{a}}$

\begin{tabular}{|rl|r|r|r|r|r|}
\hline \multicolumn{1}{|l|}{ Model } & \multicolumn{2}{|c|}{$\begin{array}{l}\text { Unstandardized } \\
\text { Coefficients }\end{array}$} & \multicolumn{1}{|c|}{$\begin{array}{c}\text { Standardized } \\
\text { Coefficients }\end{array}$} & \multirow{2}{*}{ Sig. } \\
\cline { 3 - 5 } & \multicolumn{1}{|c|}{$\mathrm{B}$} & Std. Error & \multicolumn{2}{|c|}{ Beta } & & \\
\hline \multirow{2}{*}{1} & (Constant) & 3,372 &, 885 & & 3,810 &, 000 \\
& Kepercayaan &, 045 &, 077 &, 063 &, 584 &, 560 \\
& Minat &, 375 &, 075 &, 536 & 5,009 &, 000 \\
\hline
\end{tabular}

Menurut hasil hitung pada tabel di atas menunjukan nilai koefisien yang membentuk model regresi berganda antara variabel Kepercayaan Mahasiswa (X1) dan Minat (X2) terhadap variabel Investasi Obligasi Syariah (Y). Model regresi berganda yang telah diperoleh yaitu :

$$
\mathrm{Y}=3,372+0,045 \mathrm{X} 1+0,375 \mathrm{X} 2
$$

Penjelasan dari Model regresi diatas dapat dijelaskan sebagai berikut:

1. Konstanta sebesar 3,372 yang menunjukan bahwa jika nilai X1 dan X2 tidak ada atau nol maka nilai $Y$ atau Investasi Obligasi Syariah sebesar 3,372.

2. Koefisien regresi X1 = 0,045 menunjukan bahwa jika X1 atau kepercayaan mahasiswa mengalami kenaikan 1\% maka $\mathrm{Y}$ atau investasi obligasi syariah akan mengalami kenaikan sebesar 4,5\% dengan asumsi variabel lain dianggap tetap. Hubungan searah ini dapat dilihat dari koefisien X1 dari fungsi regresi yang bernilai positif.

3. Koefisien regresi X2 $=0,375$ menunjukan bahwa jika X2 atau minat mengalami kenaikan $1 \%$ maka $\mathrm{Y}$ atau investasi obligasi syariah akan mengalami kenaikan sebesar 37,5\% dengan asumsi variabel lain dianggap tetap. Hubungan searah ini dapat dilihat dari koefisien X2 dari fungsi regrensi yang bernilai positif.

Sehingga dapat dihasilkan variabel kepercayaan mahasiswa dan variabel minat secara parsial berpengaruh signifikan terhadap investasi obligasi syariah.

\section{Tabel. 5 Koefisien Determinasi}

Model Summary

\begin{tabular}{|c|c|c|c|c|}
\hline Model & $\mathrm{R}$ & $\mathrm{R}$ Square & $\begin{array}{c}\text { Adjusted R } \\
\text { Square }\end{array}$ & $\begin{array}{c}\text { Std. Error of } \\
\text { the Estimate }\end{array}$ \\
\hline 1 &, $578^{\mathrm{a}}$ &, 334 &, 320 & 1,251 \\
\hline
\end{tabular}

a. Predictors: (Constant), Minat (X2), Kepercayaan (X1)

b. Dependent Variabel: Investasi Obligasi Syariah (Y)

Dalam perhitungan diatas telah ditunjukan dalam data yakni variable minat dan kepercayaan mahasiswa terjadi suatu hubungan terhadap produk bersertifikasi halal sebesar 0,578. Lalu nilai 
koefisien detrminasi atau $\mathrm{R}$ square sebesar 0,334 atau sebesar 33,4\% yang memiliki arti bahwa sebuah variable kepercayaan mahasiswa dan minat memiliki hubungan atau pengaruh terhadap satu sama lain sebesar $33,4 \%$ terhadap variable terikat terhadap investasi obligasi syariah lalu sisanya dipengaruhi oleh faktor lain.

\section{Penutup}

Pada penelitian yang memakai analisis kuantitaf dengan metode menyebar kuisioner dan memilih beberapa sampel responden yang berjumlah 100 orang dari mahasiswa UIN Bandung untuk syarat adalah seorang yang mempunyai minat atau bahkan sudah pernah berinvestasi di obligasi syariah. Dapat disimpulakan dari perhitungan diatas berdasarkan uji korelasi Kepercayaan mahasiswa dan Minat secara simultan berpengaruh terhadap Investasi Obligasi Syariah. Berdasarkan uji determinasi kepercayaan mahasiswa berpengaruh signifikan secara parsial terhadap investasi obligasi syariah masing masing berjumlah 0,578 dan $33,4 \%$.

\section{Daftar Pustaka}

Adisasmita, Rahardjo. 2013. Teori-teori Pembangunan Ekonomi. Yogyakarta: Graha Ilmu.

Ashhari, Z. M., L. S. Chun, dan A. M. Nassir. 2009. Conventional vs Islamic Bond Announcements: The Effects on Shareholders' Wealth. International Journal of Business and Management 4(6)

Baridwan, Zaki.2004. Intermediate Accounting. Yogyakarta: BPFE Yogyakarta

Harnanto. 2006. Survai Minat. Jakarta:Prenada Media.

Huda, Nurul dan Mustofa Edwin Nasution. 2009. Current Issues Lembaga Kenangan Syariah. Jakarta:Prenada Media.

Jorion, P. 2007. Value at Risk: The New Benchmark for Managing Financial Risk. Third Edition. Singapore: McGraw-Hill International Edition.

Junaedi.1990. Transaksi Jual Beli Saham danObligasi di Pasar Modal Indonesia di Tinjau dari Segi Hukum Islam. Jakarta: Kalam Mulia.

Koesoamah, Rahajoe. 1995. Datje, Kamus Belanda Indonesia. Jakarta: Rineka Cipta.

Obadović, M., Petrovic, E., Vunjak, N., dan Ilic, M. 2016. Assessing the Accuracy of Deltanormal VaR Evaluation for Serbian Government Bond Portfolio. Economic researchEkonomska istraživanja. Vol. 29, No.1 : 475-485.

Pandutama, Arvian. 2012. "Faktor-faktor yang Mempengaruhi Peringkat Obligasi pada Perusahaan Manufaktur di BEI”. Jurnal Ilmiah Mahasiswa Akuntansi, Vol. 1, No. 4, Juli 2012

Saparinah, dkk. 1982. Psikologi Olahraga: Buku Tuntunan. Jakarta: Depdikbud.

Sudarsono, Heri. 2004. Bank dan Lembaga Kenangan Syariah Deskripsi dan Ilustrasi. Yogyakarta: Ekonisia.

Sumarwan Ujang. 2002. Perilaku Konsumen: Teori dan Penerapannya dalam Pemasaran. Bogor: Ghalia Indonesia.

Sumitro, Warkum. 2004. Asas-asas Perbankan Islam dan Lembaga-lembaga Terkait (BAMUI, Takaful, dan Pasar Modal Syari'ah) di Indonesia. Jakarta: Raja Grafindo Persada.

Syahyuti, "Review dari Sepulub Penelitian tentang Berbankan Syariah," 2005, h. 6, data dapat diperoleh pada web. www.undip.co.id diakses pada tangal 15 Februari 2011. 